\title{
Extremely Thermophilic Acidophilic Bacteria Convergent with Sulfolobus acidocaldarius
}

\author{
By M. DE ROSA AND A. GAMBACORTA \\ CNR Laboratorio per la Chimica e Fisica di Molecule di Interesse Biologica, \\ Arco Felice, Naples, Italy \\ AND J. D. BU'LOCK \\ Microbial Chemistry Laboratory, Department of Chemistry, \\ The University, Manchester $M$ I $39 P L$
}

(Received 4 July 1974; revised 26 August 1974)

\section{SUMMARY}

A series of extremely thermophilic acidophilic bacteria has been characterized as closely resembling the species Sulfolobus acidocaldarius except for a totally different guanosine-cytosine content in the DNA; some conceptual consequences of this situation are discussed. Both organisms also share special features, including a very characteristic type of ether lipid, with other extreme acidophilic thermophiles.

\section{INTRODUCTION}

There has recently been increasing interest in the characterization of extremely thermophilic bacteria, particularly those which are also adapted to strongly acidic conditions such as hot springs in certain volcanic areas. Brock, Brock, Belly \& Weiss (1972) have described from such sources a small pleiomorphic bacterium, Sulfolobus acidocaldarius, strains of which grow at temperatures as high as $85^{\circ} \mathrm{C}$ and $\mathrm{pH}$ values as low as $\mathrm{I} \cdot \mathrm{O}$. This facultative sulphur autotroph is at least partly responsible for the formation of sulphuric acid from volcanic sulphur in such locations (Eliermans \& Brock, 1972). Earlier, Darland, Brock, Samsonoff \& Conti (1970) described a mycoplasma-like organism from burning coal-tips, Thermoplasma acidophila, growing at up to $65^{\circ} \mathrm{C}$ at $\mathrm{pH}$ values down to 0.5 ; more recently Brierley \& Brierley (1973) described a pleiomorphic bacterium rather similar to $S$. acidocaldarius but obligately autotrophic on sulphur or ferrous iron, growing at up to $70^{\circ} \mathrm{C}$ at pH I or above.

Though these three organisms seem to be distinct in several ways, they also share many characteristic features, presumably adaptive for their extreme habitats. We describe a series of isolates from a natural thermal acid source which appear indistinguishable from S. acidocaldarius except in the guanosine-cytosine (GC) content of their DNA, such that on this evidence alone they could be assigned to a different genus. We offer this account as evidence of the almost complete evolutionary convergence that is likely to be encountered in organisms from such extreme habitats. In an accompanying paper (Millonig, de Rosa, Gambacorta \& Bu'Lock, 1975) the morphology, ultrastructure and mode of division of these organisms are described; the present paper gives their physiological and chemical characteristics with some discussion of their relationship to other extremely acidophilic thermophiles. 


\section{METHODS}

Sources. In the Pisciarelli solfatara (Agnano, near Naples, Italy) are a series of small hot springs whose acidity is due to sulphuric acid, with an abundance of sulphur in the surrounding soil and on the water surfaces. The analyses (Table I) were carried out by conventional methods, calcium and magnesium being assayed compleximetrically, iron colorimetrically with $o$-phenanthroline, sulphate turbidimetrically as $\mathrm{BaSO}_{4}$, chloride by $\mathrm{Mohr}$ titration, and sulphide plus sulphite by iodometric titration.

Isolation. Samples of thermal water from the temperature range 74 to $89{ }^{\circ} \mathrm{C}$ and the $\mathrm{pH}$ range $\mathrm{I} \cdot 4$ to $2 \cdot 6$, were collected in sterile bottles and enriched as soon as possible with $0 \cdot 1 \%$ yeast extract (Difco), adjusting the $\mathrm{pH}$ to $2 \cdot 0$ with $\mathrm{H}_{2} \mathrm{SO}_{4}$ or $\mathrm{NaOH}$. Cultures usually became markedly turbid after 3 days' incubation at $75^{\circ} \mathrm{C}$; pure strains were obtained by two serial transfers from these cultures in fresh medium (see below).

Culture conditions. The standard culture medium comprised $(\mathrm{g} / \mathrm{l})$ : yeast extract (Difco), $\mathrm{I} \cdot 0$; Casamino acids (Difco), I.0; $\mathrm{KH}_{2} \mathrm{PO}_{4}, 3 \cdot \mathrm{I} ;\left(\mathrm{NH}_{4}\right)_{2} \mathrm{SO}_{4}, 2 \cdot 5 ; \mathrm{MgSO}_{4} \cdot 7 \mathrm{H}_{2} \mathrm{O}, 0 \cdot 20$; $\mathrm{MgCl}_{2} .2 \mathrm{H}_{2} \mathrm{O}, 0 \cdot 25$; tap water to $\mathrm{I} 1, \mathrm{pH}$ adjusted with $\mathrm{H}_{2} \mathrm{SO}_{4}$. All $\mathrm{pH}$ values (high-temperature glass electrode) are corrected for the effect of temperature; for both natural sources and culture media the $\mathrm{pH}$ increases by 0.004 unit $/{ }^{\circ} \mathrm{C}$.

In experiments with other carbon sources these were added at $2.0 \mathrm{~g} / \mathrm{l}$ in place of the yeast extract and Casamino acids; in experiments on amino acid utilization, again at $2 \cdot 0 \mathrm{~g} / \mathrm{l}$, the ammonium sulphate was also omitted from the medium.

For autotrophic growth, sublimed sulphur $\left(\mathrm{S}_{8}\right)$ was added at $10 \mathrm{~g} / \mathrm{l}$ to the standard medium, and from a growth thus obtained an inoculum was transferred to basal salts medium with $\mathrm{I} 0 \mathrm{~g} \mathrm{~S}_{8} / \mathrm{l}$; the culture vessel was gassed with $\mathrm{CO}_{2}$ for $30 \mathrm{~s}$, then closed and incubated for 7 to Io days; growth was followed visually and by $\mathrm{pH}$ decrease.

For autotrophic growth on ferrous iron, $100 \mathrm{ml}$ of the basal salts solution was supplied with $2 \mathrm{ml}$ of sterile solution containing $25 \mathrm{~g}$ of $\mathrm{FeSO}_{4} \cdot 7 \mathrm{H}_{2} \mathrm{O}$ in $95 \mathrm{ml}$ distilled water and $5 \mathrm{ml} 0.5 \mathrm{M}-\mathrm{H}_{2} \mathrm{SO}_{4}$. The flasks were inoculated with exponential phase cells centrifuged quickly from an optimal culture; after 5 days at $75^{\circ} \mathrm{C}, \mathrm{pH} 3 \cdot 0$, the $\mathrm{Fe}^{3+}$ ion was assayed with $0 \cdot 0 \mathrm{I} \mathrm{N}-\mathrm{KMnO}_{4}$ after acidification with $\mathrm{I} \mathrm{M}-\mathrm{H}_{2} \mathrm{SO}_{4}$.

For normal (heterotrophic) growth, small cultures were incubated either statically in ovens or in a gyrorotatory water bath. Larger cultures $(251)$ were grown in a Terzano fermenter with slow agitation (20 rev./min or less) and aeration $(2.5$ to $3.01 / \mathrm{min})$.

Growth was quantified turbidimetrically at $540 \mathrm{~nm}$; a turbidity of 0.4 ( $10 \mathrm{~mm}$ cell) corresponds to $0.54 \mathrm{~g}$ dry cells/l. Cells were normally recovered by centrifuging at $20000 \mathrm{~g}$.

Stock cultures were maintained by cooling cultures grown on the standard medium to $4{ }^{\circ} \mathrm{C}$ and correcting the $\mathrm{pH}$ to $6 \cdot 0$, and were then renewed at monthly intervals.

Lysis. Cells were not lysed by lipase (Fluka) or lysozyme (Boehringer) added to the suspen-

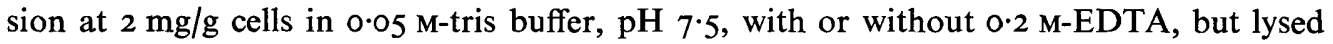
rapidly with $0.5 \%$ sodium lauryl sulphate.

Isolation and characterization of DNA. Growth-phase cells were lysed with $0.5 \%$ sodium lauryl sulphate in $0.05 \mathrm{M}$-tris buffer with $0.15 \mathrm{M}-\mathrm{NaCl}$, and the DNA isolated and purified by the method of Marmur (196I). Hydrolysis (Wyatt \& Cohen, 1953) and separation of the bases by paper chromatography, followed by spectrophotometric assay (Bendich, 1957) was used to determine the guanosine and cytosine content. Alternatively, the DNA sample, following dialysis against $10 \%(\mathrm{v} / \mathrm{v}) \mathrm{SSC}(\mathrm{SSC}=0.15 \mathrm{M}-\mathrm{NaCl}, 0.015 \mathrm{M}$-sodium citrate, $\mathrm{pH} 7$ ), was examined by ultracentrifuging in a $\mathrm{CsCl}$ gradient using $\mathrm{I}$ extinction unit of DNA for each gradient, with an internal standard of Xenopus laevis DNA ( $\%$ GC, 39.5), 0.004 
extinction unit/gradient, labelled with ${ }^{14} \mathrm{C}\left(3 \times 10^{4}\right.$ counts $\left./ \mathrm{min} / \mathrm{mg}\right)$. The gradient $(4 \cdot \mathrm{I} \mathrm{ml}$, $n_{\mathrm{D}}^{25} \mathrm{I} \cdot 4005$ ) was established with a Spinco L2/65 B angular rotor 40 at $35000 \mathrm{rev} . / \mathrm{min}$ for $72 \mathrm{~h}$. Fractions of $0.0 \mathrm{I} \mathrm{ml}$ were taken and diluted to $0.5 \mathrm{ml}$ with $10 \%$ (v/v) SSC. Total DNA was measured spectrophotometrically. The marker DNA was localized by precipitation with cold $5 \%$ trichloroacetic acid and carrier bovine serum albumen for counting on glass-fibre filters. The \% GC was calculated by the methods of Sueoka, Marmur \& Doty (1959).

Antibiotic sensitivity. Sensitivity of the MT isolates and of a culture of Bacillus acidocaldarius (Agnano strains) to vancomycin (hydrochloride, Eli Lilley) and novobiocin (Ca salt, Boots Ltd) was established by the procedure of Brock et al. (1972).

Amino sugars. Lyophilized cells $(50 \mathrm{mg})$ were treated with $4 \mathrm{M}-\mathrm{HCl}(5 \mathrm{ml})$ for $4 \mathrm{~h}$ at $100{ }^{\circ} \mathrm{C}$, and the hydrolysate evaporated to dryness in vacuo (over $\mathrm{P}_{2} \mathrm{O}_{5}$ and $\mathrm{NaOH}$ ) and taken up in water. After passage through a Dowex $50\left(\mathrm{H}^{+}\right)$column, eluting first with water and then with $\mathrm{M}$-aqueous ammonia, the eluate was chromatographed on Whatman $3 \mathrm{MM}$ paper (descending; 4:I:5, butanol-acetic acid-water). The Elson-Morgan-positive spots were eluted and assayed spectrophotometrically (Ashwell, 1957) as glucosamine.

Lipids. Total lipid was extracted from lyophilized cells by Soxhlet extraction $(48 \mathrm{~h})$ in I: I chloroform solution. The resolution of the lipid classes was carried out on a silica gel column (Merck Kieselgel 60, 230 mesh), eluting with chloroform (neutral lipids), acetone (glycolipids) and methanol (phospholipids). For experiments with labelled precursors sodium $\left[2{ }^{14} \mathrm{C}\right]$ acetate $(610 \mu \mathrm{Ci} / \mathrm{mg})$ was purchased from New England Nuclear Corp., Boston, Massachusetts, U.S.A.; DL-[2-14 C]mevalonolactone $(99 \mu \mathrm{Ci} / \mathrm{mg})$ was purchased from The Radiochemical Centre, Amersham, Buckinghamshire. In this experiment, the organism was grown in 251 batch cultures and the labelled substrate, sodium $\left[2-{ }^{14} \mathrm{C}\right]$ acetate $(0.25 \mathrm{mCi})$ or $\mathrm{DL}-\left[2{ }^{14} \mathrm{C}\right] \mathrm{mevalonolactone}(0.25 \mathrm{mCi})$, added to the cultures at the beginning of the exponential phase over a $3 \mathrm{~h}$ period by a peristaltic pump. Cells were harvested in the stationary phase by continuous-flow centrifugation, then washed with $0 \cdot \mathrm{I} \mathrm{M}-\mathrm{NaCl}$, freezedried and extracted continuously (Soxhlet). The lipid extract was evaporated and treated with $37 \% \mathrm{HCl}$ in methanol $(6 \%, \mathrm{v} / \mathrm{v})$ under reflux; after $6 \mathrm{~h}$ the mixture was diluted with water $(\mathrm{I}: \mathrm{I})$ and extracted three times with $n$-hexane. This extract was chromatographed on a silica gel column (Merck Kieselgel 60, 230 mesh) in light petroleum (b.p. 40 to $70{ }^{\circ} \mathrm{C}$ ) and increasing amounts of ether; the cyclic glycerol diether was recovered in the $50 \%$ ether fractions as a viscous oil. The radioactivity was measured by a Beckman LS-250 liquid scintillation system [efficiency 88 to $91 \%$ by internal standardization in $\mathrm{I} 0 \mathrm{ml}$ of the following solution: toluene, I 1; 2,5-diphenyloxazole (PPO), Io g; I,4-di(2-(4-methyl-5-phenyloxazolyl))-benzene (dimethyl POPOP), $0.5 \mathrm{~g}$ ].

\section{RESULTS}

\section{Isolation}

Samples of thermal water were collected in the Pisciarelli solfatara, from small pools with a temperature range of 74 to $89{ }^{\circ} \mathrm{C}$ and a $\mathrm{pH}$ range of $\mathrm{I} \cdot 4$ to 2.6 ; these waters generally contain about $5 \mathrm{~g}$ dissolved salts/1, and a proximate analysis of a typical sample is given in Table I. By enrichment and serial transfer (see Methods) six isolates were obtained, of which four showed maximum growth temperatures of $85{ }^{\circ} \mathrm{C}$, one $80{ }^{\circ} \mathrm{C}$, and one $89{ }^{\circ} \mathrm{C}$. Two strains, designated MT3 and MT4, were retained for further study; unless specified, data refer primarily to the MT3 strain. 
Table I. Proximate analysis of thermal water sample from Pisciarelli
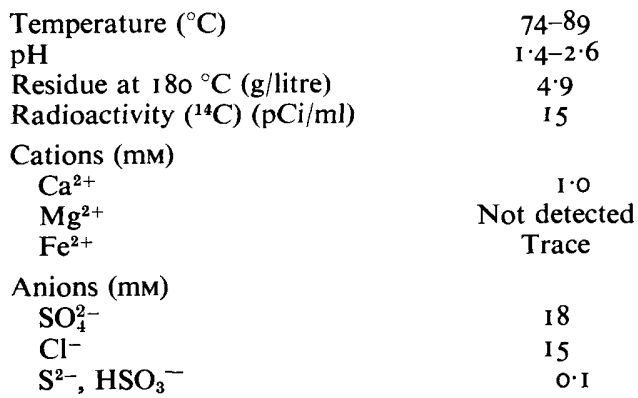

Temperature $\left({ }^{\circ} \mathrm{C}\right)$

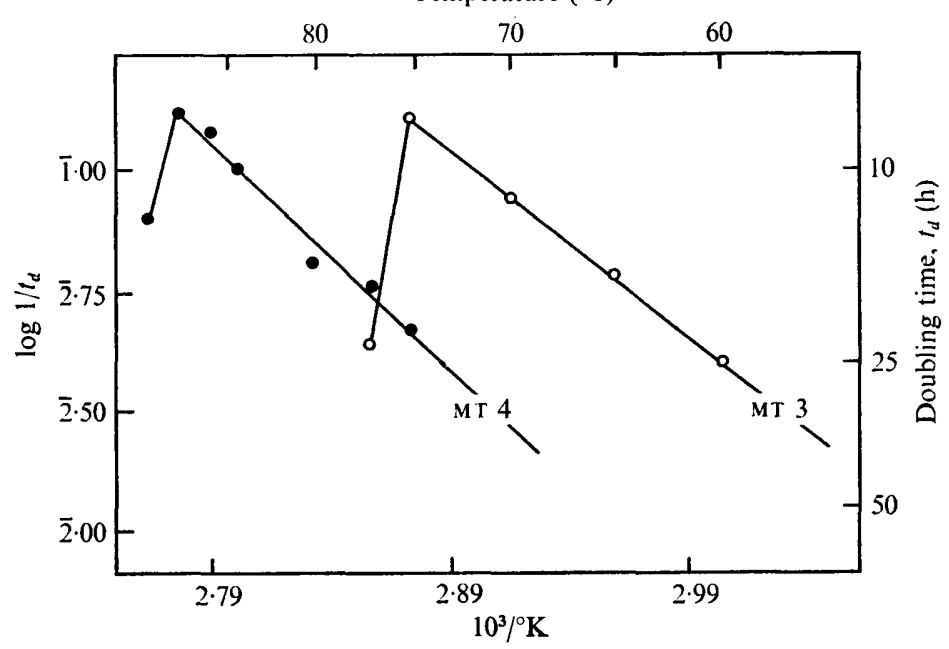

Fig. I. Arrhenius plots of growth of MT3 and MT4 at pH $3 \cdot 0$.

\section{Maintenance}

We were unable reliably to maintain cultures on agar media, or by freezing $\left(-20{ }^{\circ} \mathrm{C}\right)$ or lyophilization. Cultures were therefore maintained on liquid media (see Methods). It was observed that cultures which were cooled from the optimum growth temperature rapidly lost viability if left at the 'optimum' $\mathrm{pH}(2 \cdot 0$ to $3 \cdot 0)$ but remained viable at the lower temperature if the $\mathrm{pH}$ of the medium was raised, e.g. to 6.0. Cultures of $\mathrm{MT} 3$ are deposited at the Torry Research Station, Aberdeen.

\section{Morphology}

The morphology and ultrastructure of MT isolates are fully described in the accompanying paper (Millonig et al. 1975). Under phase contrast the organism is spherical, about $\mathrm{I} \cdot 0 \mu \mathrm{m}$ in diameter, revealing some irregularity ('tumbling') when in Brownian motion, somewhat less marked than in S. acidocaldarius (Brock et al. 1972, and our own observations). No viable cells passed through a membrane filter with $0.45 \mu \mathrm{m}$ pores. Cells are deformed or destroyed in smear preparations, indicating the lack of a rigid cell envelope; on exposure to $\mathrm{pH}_{3} \cdot \mathrm{O}$ at room temperature cells become vacuolated and the contents coagulate. 
Table 2. Effect of $p H$ on growth rate of $\mathrm{MT} 3$ at $75^{\circ} \mathrm{C}$

$\begin{array}{lrrrrr}\mathrm{pH} & \mathrm{I} \cdot 5 & 2 \cdot 0 & 2 \cdot 5 & 3.0-4.5 & 5.0 \\ \text { Doubling time (h) } & 20.0 & 17 \cdot 0 & 12.0 & 7.9 & 10.5\end{array}$

Table 3. Growth and $\mathrm{Fe}^{2+}$ oxidation in cultures of MT3

$\begin{array}{lcc}\text { Culture } & \begin{array}{c}\text { Final Fe } \\ (\mathrm{mg} / \mathrm{ml})\end{array} & \text { Growth } \\ \text { Basal salts } & \mathrm{I} .05 & +++ \\ \quad \text { Inoculated } & 0.64 & - \\ \quad \text { Not inoculated } & & \\ \text { Basal salts }+0 . \mathrm{I} \% \text { yeast extract } & 0.9 \mathrm{I} & ++ \\ \quad \text { Inoculated } & 0.6 \mathrm{I} & -\end{array}$

Cultures were incubated for 5 days; total Fe was $1 \mathrm{mg} / \mathrm{ml}$.

\section{Temperature and $\mathrm{pH}$ effects}

The temperature range of cultures of MT3 and MT4 grown at $\mathrm{pH} 3.0$ is shown by the Arrhenius plots, Fig. I. Strain MT3 grows in the range 50 to $80^{\circ} \mathrm{C}$, optimally at $75^{\circ} \mathrm{C}$ and not detectably at 45 or at $83{ }^{\circ} \mathrm{C}$. Strain MT4 grows in the range 63 to $89{ }^{\circ} \mathrm{C}$, optimally at $87^{\circ} \mathrm{C}$ and not detectably at 60 or at $92^{\circ} \mathrm{C}$. At the optimal temperatures, $\mathrm{pH} 3.0$, the doubling times for MT3 and MT4 were 7.9 and $7.5 \mathrm{~h}$ respectively. Above the normal growth range, strain MT3 remained viable after 30 to $60 \mathrm{~min}$ at $90^{\circ} \mathrm{C}$ but not after I $20 \mathrm{~min}$; strain MT4 survived $100{ }^{\circ} \mathrm{C}$ for 5 and $\mathrm{I} 5 \mathrm{~min}$ but was killed after $30 \mathrm{~min}$.

At optimal temperatures, broad $\mathrm{pH}$ optima were found from $\mathrm{pH} 3.0$ to $\mathrm{pH} 4.5$, but there was no growth at $\mathrm{pH} \mathrm{I}^{\circ} \mathrm{O}$ or 5.5 (Table 2 ).

Measured by turbidity, growth in optimal conditions reached typical maxima at an $E_{540}$ of 0.3 in static cultures and 0.45 in fermenter cultures, corresponding to about 0.37 and $0.54 \mathrm{~g}$ dry cells/l respectively.

\section{Heterotrophic growth}

No MT isolates grew heterotrophically under nitrogen. Good growth was obtained on media with yeast extract, tryptone, or Casamino acids, provided that their concentration was not greater than $0.2 \%$. Growth is markedly inhibited at higher nutrient concentrations, as in Sulfolobus and Thermoplasma. On defined media (containing $\mathrm{NH}_{4}$ salts), both $\mathrm{MT}_{3}$ and MT4 utilized glucose, xylose, sucrose, lactose, maltose or rhamnose as sole carbon source, but not cellobiose, sorbitol, or mannitol; supplied as sole carbon and nitrogen sources, amino acids (glycine, valine, leucine, arginine, lysine, alanine, glutamate, aspartate, serine, methionine) did not support growth. The organisms are less nutritionally demanding than Thermoplasma and their range of heterotrophic nutrition is within that described for S. acidocaldarius (Brock et al. 1972). The organisms are not even moderately halophilic, since no growth is observed when $\mathrm{I} \%(\mathrm{w} / \mathrm{v}) \mathrm{NaCl}$ is added to the standard medium.

\section{Autotrophic growth}

After passage from heterotrophic growth on yeast extract through yeast extract-sulphur medium to a medium supplied only with sulphur, $\mathrm{CO}_{2}$ and inorganic salts, moderate growth occurred during 7 days, confirmed by direct phase-contrast microscopy, and the $\mathrm{pH}$ was decreased from 3.5 initially to $2 \cdot 2$. Autotrophic growth also occurred with ferrous iron as the oxidizable substrate, but iron oxidation was not more marked in the presence of yeast extract (Table 3). Sulfolobus likewise shows facultative autotrophic growth on sulphur but 


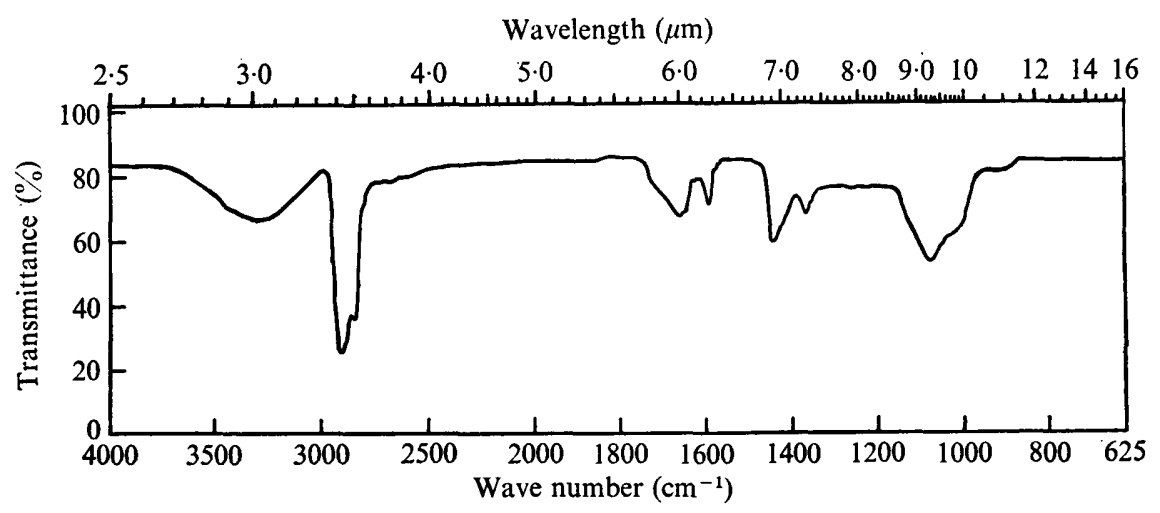

Fig. 2. Infrared spectrum, in chloroform solution, of total lipids of strain MT3.

iron autotrophy was not noted (Brock et al. 1972); Thermoplasma is an obligate heterotroph (Darland et al. 1970) and the organism of Brierley \& Brierley (1973) is obligatorily autotrophic for sulphur or iron.

\section{Coat substance, antibiotic sensitivity, and lysis}

As judged by electron microscopy (Millonig et al. 1975) the structured extra-membrane material of MT cells, which does not confer rigidity to the cells, is not peptidoglycan; analytically, the cells contain a small proportion of glucosamine $(9 \mathrm{mg} / \mathrm{g}$ dry wt in MT4, I I $\mathrm{mg} / \mathrm{g}$ dry wt in MT3). Sulfolobus contains similar amounts of glucosamine, which is absent in Thermoplasma (Brock et al. 1972). All MT strains were resistant to vancomycin, which blocks muramic acid transfer, at concentrations $\leqslant 5.0 \mathrm{mg} / \mathrm{ml}$, but susceptible to novobiocin at or above $0.01 \mathrm{mg} / \mathrm{ml}$; as a control, Bacillus acidocaldarius was inhibited by $0.005 \mathrm{mg}$ or more novobiocin $/ \mathrm{ml}$ and $0.020 \mathrm{mg}$ or more vancomycin $/ \mathrm{ml}$. The antibiotic sensitivity of the MT strains parallels that of Sulfolobus (Brock et al. 1972) and Thermoplasma (Darland et al. 1970).

At neutral $\mathrm{pH}$ and room temperature, cells were not lysed by lysozyme and/or lipase, with or without added EDTA, but were rapidly and completely lysed by $0.5 \%$ sodium lauryl sulphate. Similar properties are more fully described for $T$. acidophila (Belly \& Brock, I972). On lysis of centrifuged cells the pH rose from 3.5 to 6.3 , suggesting that the intracellular $\mathrm{pH}$ is close to neutrality.

\section{Lipids}

Lyophilized MT cells contain about $10 \%(\mathrm{w} / \mathrm{w})$ total lipids, comprising $70 \%$ polar lipids, $10 \%$ less polar, and $20 \%$ neutral lipids, approximately. The infrared spectrum of the total lipids (Fig. 2) is very characteristic, showing the total absence of ester linkages (no peak at $1640 \mathrm{~cm}^{-1}$ ) and a high proportion of ether links (signal at I $100 \mathrm{~cm}^{-1}$ ). The predominantly isoprenoid nature of the alkyl component of these lipids is apparent from the selectivity with which $\left[2-{ }^{14} \mathrm{C}\right] \mathrm{mevalonate}$ is incorporated into the total lipids (Table 4 ). We have made parallel observations on the lipids of $S$. acidocaldarius, with essentially similar results, and chemical details are given elsewhere (de Rosa, Gambacorta, Minale \& Bu'Lock, I974a). 
Table 4. Incorporation of $\left[2-{ }^{14} \mathrm{C}\right]$ acetate and $\mathrm{DL}-\left[2-{ }^{14} \mathrm{C}\right]$ mevalonolactone into MT3 lipids

\begin{tabular}{|c|c|c|}
\hline & \multicolumn{2}{|c|}{ Percentage incorporation into } \\
\hline Precursor & Total lipids & $\begin{array}{c}\text { Cyclic glycerol } \\
\text { diether* }\end{array}$ \\
\hline$\left[2-{ }^{14} \mathrm{C}\right]$ acetate $\dagger$ & $2 \cdot 6$ & $I \cdot 74$ \\
\hline DL- $\left[2-{ }^{14} \mathrm{C}\right]$ mevalonolactone & $10 \cdot 7$ & $3 \cdot 21$ \\
\hline
\end{tabular}

\section{DNA base composition}

High molecular weight DNA, homogeneous in the ultracentrifuge and apparently free from satellite DNA species, was prepared from both MT3 and MT4 cultures. By quantitative chromatographic separation of the bases, after hydrolysis, the \% GC for MT3 was determined as $42 \%$ and that for MT4 as $39 \%$. By preparative $\mathrm{CsCl}$-gradient ultracentrifugation in a mixture with ${ }^{14} \mathrm{C}$-labelled Xenopus laevis DNA ( $\%$ GC, 39.5) values of 45 and $39 \%$ were obtained for these samples.

Because these values were so dramatically different from the range reported by Brock et al. ( 1972 ) for $S$. acidocaldarius ( $\%$ GC, 60 to 68 ), which in other respects the MT isolates so closely resemble (see Discussion), we sought an independent determination. Samples of high molecular weight DNA were prepared from MT3 and from a culture of S. acidocaldarius strain 98/3 (stock culture provided by J. A. Mosser), and despatched under coded labels to $\mathrm{Dr} \mathrm{S}$. Ayad (Department of Biochemistry, University of Manchester) who by analytical $\mathrm{CsCl}$

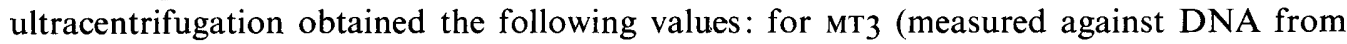
Micrococcus lysodeikticus), $\rho^{25}=\mathrm{I} \cdot 707 \mathrm{~g} / \mathrm{cm}^{3}, \% \mathrm{GC}=47 \cdot 9$; for $S$. acidocaldarius (measured against DNA from Bacillus subtilis), $\rho^{25}=1 \cdot 729 \mathrm{~g} / \mathrm{cm}^{3}, \%$ GC $=70 \cdot 4$.

\section{DISCUSSION}

As already noted (de Rosa, Gambacorta, Millonig \& Bu'Lock, 1974 $b$ ), the MT series of isolates is extremely similar to the organisms designated as $S$. acidocaldarius by Brock et al. (I972), and the majority of the results presented here are to be taken as substantiating the closeness of this resemblance. However, the two are not strictly identical, the most fundamental difference being in the \% GC content of the DNA. The magnitude of this difference would, in other circumstances, be taken to indicate not merely different species but also different genera. However, in the present case it accompanies the kind of close similarity in other characters which would be expected between different strains of the same species. These organisms are indigenous to particularly stringent habitats in which we would a priori expect strong convergence of characters, and in an extreme case these convergent adaptive characters may so totally dominate descriptions of the organisms that the normal indicators of phyletic affinity, other than the GC content, are no longer accessible. In our preliminary account (de Rosa et al. $1974 b$ ) we argued that until more satisfactory discriminatory criteria are available, both the MT organisms and $S$. acidocaldarius should be classed together, in a 'form/habitat' group, Caldariella, which would also include both the mycoplasma-like T. acidophila of Darland et al. (1970) and the un-named pleiotropic Fe, S autotrophic organism of Brierley \& Brierley (1973). The latter has a GC ratio of 54 to $60 \%$; for 
Thermoplasma, Belly \& Brock (I972) report 24 to $28.5 \%$ GC, but Freundt (I972) gives a revised figure of $46 \%$ which is within our range for MT isolates. We would note recent implications of considerable heterogeneity amongst organisms morphologically classed as S. acidocaldarius (Mosser, Mosser \& Brock, I974; Bohlool \& Brock, 1974).

Some aspects of our data for the MT organisms which either differ from or extend descriptions of $S$. acidocaldarius, additional to those in the accompanying paper (Millonig et al. I975), require comment.

The need to devise conditions for the maintenance of liquid cultures as stock led to observations which clearly demonstrate that acid-tolerance in MT is an active process dependent upon continued metabolism. In particular, if cultures growing at the optimum temperature and $\mathrm{pH}$ are cooled to temperatures at which active growth no longer occurs, viability is lost and the cell contents are irreversibly altered. To maintain viability at sub-optimal temperatures it is necessary to provide a medium in which the hydrogen ion concentration is substantially closer to that which apparently exists inside the cells, a clear indication that acidophily depends upon the existence of metabolically driven mechanisms for maintaining the $\mathrm{pH}$ gradient across the cell membrane.

The very characteristic isoprenoid ether lipids of MT3 (unpublished) are also found, with quantitative differences only, in $S$. acidocaldarius. They are based on a cyclic diether of glycerol and a unique bifunctional saturated isoprenoid $\mathrm{C}_{40}$ moiety (de Rosa et al. 1974a), and they are closely related to (or identical with) those partly characterized in Thermoplasma acidophila by Langworthy, Smith \& Mayberry (1972). These lipids might well constitute a chemical marker for the 'Caldariella' group, just as the biogenetically related diphitanyl glycerol diether lipids of Halobacterium cutirubrum constitute a marker for the polyphyletic assembly of extreme halophiles (Kates, 1972). In both cases, the replacement of ester-linked by ether-linked lipids is presumably advantageous in stabilizing the membrane towards environmental stress, and indeed on naive chemical grounds it would seem more obviously advantageous in the extreme acidophiles. However, it is the branched and cyclic nature of the hydrophobic moiety which may be the more significant characteristic, since this will tend to form bilayers which are densely but irregularly packed, the effect being similar to that produced by the incorporation of cholesterol into normal acyl-lipid bilayers. This will both stabilize and fluidize the bilayer system and may prove to be a key factor in permitting these organisms to function in their extreme habitat.

We are particularly grateful to Dr A. J. Powell for his interest and advice in this investigation, and to Dr S. Ayad and Dr E. Beccari for the DNA measurements. We also thank Dr J. A. Mosser for a culture of S. acidocaldarius, and E. Esposito and S. Sodano for technical assistance.

\section{REFERENCES}

AshWell, G. (1957). Colorimetric analysis of sugars. In Methods in Enzymology, vol. 3, pp. 95-97. Edited by S. P. Colowick and N. O. Kaplan. New York: Academic Press.

BeLly, R. T. \& BRoCK, T. D. (I972). Cellular stability of a thermophilic acidophilic mycoplasma. Journal of General Microbiology 73, 465-469.

BENDICH, A. (1957). Methods for characterization of nucleic acids by base composition. I. Methods of hydrolysis. In Methods in Enzymology, vol. 3, pp. 716-723. Edited by S. P. Colowick and N. O. Kaplan. New York: Academic Press.

Bohlool, B. B. \& Brock, T. D. (1974). Population ecology of Sulfolobus acidocaldarius. II. Immunoecological studies. Archives of Microbiology 97, 18 I-194.

Brierley, C. L. \& Brierly, J. A. (1973). A chemoautotrophic and thermophilic microorganism isolated from an acid hot spring. Canadian Journal of Microbiology 19, 183-188. 
Brock, T. D., Brock, K. M., Belly, R. T. \& Weiss, L. R. (1972). Sulfolobus: a new genus of sulfur-oxidizing bacteria living at low $\mathrm{pH}$ and high temperature. Archiv für Mikrobiologie 84, 54-68.

Darland, G., Brock, T. D., Samsonoff, W. \& Conti, S. F. (1970). A thermophilic, acidophilic Mycoplasma isolated from a coal refuse pile. Science, New York 170, 1416-1418.

Eliermans, C. B. \& Brock, T. D. (1972). Ecology of sulfur-oxidizing bacteria in hot acid soils. Journal of Bacteriology I1 $1343-350$

Freundt, E. A. (1972). In Pathogenic Mycoplasmas (CIBA Symposium), p. Io. Edited by K. Elliott and J. Birch. Amsterdam: Elsevier.

KATES, M. (1972). Ether-linked lipids in extremely halophilic bacteria. In Ether Lipids: Chemistry and Biology, pp. 35I-398. Edited by F. Snyder. New York: Academic Press.

Langworthy, T. A., Smith, P. F. \& Mayberry, W. R. (1972). Lipids of Thermoplasma acidophilia. Journal of Bacteriology I12, I 193-I 200.

MARMUR, J. (196I). A procedure for the isolation of deoxyribonucleic acid from microorganisms. Journal of Molecular Biology 3, 208-218.

Millonig, G., de Rosa, M., Gambacorta, A. \& Bu'Lock, J. D. (1975). Ultrastructure of an extremely thermophilic micro-organism. Journal of General Microbiology 86, I65-1 73.

Mosser, J. L., Mosser, A. G. \& Brock, T. D. (1974). Population ecology of Sulfolobus acidocaldarius. I. Temperature studies. Archives of Microbiology 97, 169-179.

de Rosa, M., Gambacorta, A., Minale, L. \& Bu'Lock, J. D. (1974a). Cyclic diether lipids from very thermophilic acidophilic bacteria. Chemical Communications, 543-544.

de Rosa, M., Gambacorta, A., Millonig, G. \& Bu'Lock, J. D. (I974b). Convergent characters of extremely thermophilic acidophilic bacteria. Experientia (in the Press).

Sueoka, N., Marmur, J. \& Doty, P. (I959). Dependence of the density of deoxyribonucleic acids on guaninecytosine content. Nature, London 183, I429-143I.

WYATT, G. R. \& COHEN, S. S. (1953). The bases of nucleic acids of some bacterial and animal viruses: the occurrence of 5-hydroxymethylcytosine. Biochemical Journal 55, 774-782. 